\title{
Pichia deserticola and Candida deserticola, Two New Species of Yeasts Associated with Necrotic Stems of Cacti
}

\author{
HERMAN J. PHAFF, ${ }^{1 *}$ WILLIAM T. STARMER, ${ }^{2}$ JOANNE TREDICK, $^{1}$ AND MARY MIRANDA ${ }^{1}$ \\ Department of Food Science and Technology, University of California, Davis, California $95616^{1}$ and Department of \\ Biology, Syracuse University, Syracuse, New York $13210^{2}$
}

\begin{abstract}
We describe Pichia deserticola and Candida deserticola, two species that have as their habitats necrotic tissues of Opuntia spp. and Stenocereus spp., respectively. Pichia deserticola, 21 strains of which were isolated, is homothallic and occurs in nature exclusively in the diploid state. It produces asci with two hat-shaped spores, which are rapidly released upon maturity. This species is nonfermentative and assimilates few carbon compounds. The guanine-plus-cytosine content range of the nuclear deoxyribonucleic acid (eight strains) is 27.4 to $28.4 \mathrm{~mol} \%$, and the average \pm standard deviation for eight strains is $27.8 \pm 0.4 \mathrm{~mol} \%$. Candida deserticola, 48 strains of which were isolated, has the same phenotypic properties and deoxyribonucleic acid base composition as $\boldsymbol{P}$. deserticola, but lacks the ability to produce ascospores and is resistant to triterpene glycosides in growth media. The deoxyribonucleic acids of $P$. deserticola and $C$. deserticola show more than $96 \%$ homology, but the two species are separated geographically and by host plant. $P$. deserticola occurs in Opuntia species in southern Arizona and Texas, whereas $C$. deserticola is found almost exclusively in columnar cacti of the genus Stenocereus on certain Caribbean islands and in Baja California, Mexico. The type strain of $P$. deserticola is strain UCD-FST 83-467.3 (= ATCC $58091=$ CBS 7119), and the type strain of C. deserticola is strain UCD-FST 76-355A (= ATCC 58088 = CBS 7121).
\end{abstract}

In the fall of 1981 we began a study of the yeast flora associated with rotting cladodes of Opuntia species in Arizona and Texas (10), and a limited follow-up survey was made in Arizona in the spring of 1983. In these collections we discovered a novel, homothallic, diploid yeast which has a low-level physiological profile and a deoxyribonucleic acid (DNA) base composition of $27.8 \pm 0.4 \mathrm{~mol} \%$ guanine plus cytosine $(\mathrm{G}+\mathrm{C})$ and produces asci with two large hat-shaped ascospores that are rapidly released at maturity (reported then as Pichia sp. S). During an earlier expedition to Baja California, Mexico, we isolated 14 strains of an asporogenous yeast from various species of columnar cacti (mainly Stenocereus gummosus) that were reported as Candida sp. $\mathrm{K}$ (13) and have now been recognized as being phenotypically identical to and having the same $G+C$ content as the new species described in this paper. In 1982 and 1983, during two expeditions to various islands in the Caribbean Sea, we isolated an additional 34 strains of Candida $\mathrm{sp}$. K, mainly from the columnar cactus Stenocereus hystrix. Genome comparisons of the sporogenous yeast with the imperfect strains from Mexico and from the Caribbean islands showed that all of the strains had nearly identical base sequences. A similar comparison with other yeasts having low $G+C$ contents suggested that the sporogenous strains comprise a new species in the genus Pichia. We named the new isolates Pichia deserticola because of their unique habitat in necrotic tissues of Opuntia cacti in desert areas of the southwestern United States. The asporogenous forms are regarded as the anamorph of Pichia deserticola and are described as Candida deserticola.

\section{MATERIALS AND METHODS}

Samples of necrotic cactus tissue yielding Pichia deserticola were collected near Tucson, Ariz., in 1981 and 1983 and in Texas in November 1981 (see reference 10 for detailed

\footnotetext{
* Corresponding author.
}

locations) (Table 1). Previously (10), Pichia deserticola was referred to as Pichia sp. S. The samples of cactus yielding Candida deserticola in Baja California came from host plants and locations described in detail by Starmer et al. (13), who referred to this organism as Candida sp. K (Table 1). The samples yielding Candida deserticola on Caribbean islands were collected in May 1982 during cruise CF-8205 and in November 1983 during cruise CF-8314 of the research vessel Cape Florida in that region. The techniques used for yeast isolation and purification have been described previously (10). The strains analyzed for nuclear DNA base composition and those used in the DNA-DNA base sequence studies are listed in Table 2.

The usual phenotypic characterization of the isolates was carried out by methods currently used in yeast taxonomy (17), but additional carbon compounds were used in assimilation tests. These included D-glucosamine hydrochloride, $N$-acetyl-D-glucosamine, methanol, 2-propanol, acetone, and ethyl acetate; the last three compounds could be tested only by incorporating them at concentrations of $1.0 \%$ in yeast nitrogen base agar (Difco Laboratories, Detroit, Mich.) because in liquid yeast nitrogen base media they may have inhibited growth even in those cases where good growth occurred on solid media.

DNA extraction and purification were carried out by the methods described by Price et al. (7), except that purified DNA was concentrated by electrophoresis in a concentrator (ISCO, Lincoln, Nebr.) and the reference DNA was labeled with ${ }^{125} \mathrm{I}$ as described by Holzschu et al. (4). The $\mathrm{G}+\mathrm{C}$ contents of the nuclear DNAs were calculated from buoyant density values in cesium chloride gradients established in a Spinco model $\mathrm{E}$ analytical ultracentrifuge equipped with photographic optics $(8,15)$ and were based on three separate determinations. DNA from Micrococcus luteus strain 2039 (International Collection of Phytopathogenic Bacteria, Department of Bacteriology, University of California, Davis), with a buoyant density of $1.7309 \mathrm{~g} / \mathrm{ml}$, was used as a 
TABLE 1. Strain designations, localities, and cactus hosts of isolates studied

\begin{tabular}{|c|c|c|}
\hline UCD-FST strain no. ${ }^{\prime}$ & Locality & Host plant \\
\hline \multicolumn{3}{|l|}{ Pichia deserticola } \\
\hline $81-402 \mathrm{~B}, 81-403 \mathrm{~B}, 81-404 \mathrm{C}, 81-413 \mathrm{D}$ & Tucson Mountains & O. phaeacantha \\
\hline $81-429 \mathrm{C}$ & Santa Catalina Mountains & O. phaeacantha \\
\hline $81-448 \mathrm{C}$ & Santa Rita Mountains & O. phaeacantha \\
\hline $81-609.2,81-610.2$ & Bakersfield, Tex. & O. lindheimeri \\
\hline $81-618.2,81-626.1,81-628.2,81-629.4,81-631.2,81-632.1$ & New Brauenfels, Tex. & O. lindheimeri \\
\hline $83-413.3,83-416.2,83-420.2$ & Tucson Mountains & O. phaeacantha \\
\hline $83-436.3,83-446.4$ & Santa Rita Mountains & O. phaeacantha \\
\hline $83-467.3^{\mathrm{T}}, 83-480.1$ & Santa Catalina Mountains & O. phaeacantha \\
\hline \multicolumn{3}{|l|}{ Candida deserticola } \\
\hline $71-161,72-305$ & Southern Arizona & Carnegiea gigantea \\
\hline $76-229 \mathrm{~B}, 76-231 \mathrm{C}, 76-232 \mathrm{~A}, 76-238 \mathrm{~A}, 76-240 \mathrm{~A}$ & Todos Santos area, Baja California, Mexico & Stenocereus gummosus \\
\hline $76-242 \mathrm{~A}$ & Todos Santos area, Baja California, Mexico & S. thurberi \\
\hline $76-277 \mathrm{~A}$ & La Paz, Baja California, Mexico & S. gummosus \\
\hline $76-285 B$ & La Paz, Baja California Mexico & Prosopis juliflora slime flux \\
\hline $76-296 C$ & El Centenario, Baja California & S. thurberi \\
\hline $76-320 \mathrm{~B}$ & Loreto, Baja California, Mexico & S. gummosus \\
\hline $76-341 \mathrm{~A}$ & San Borja, Baja California, Mexico & S. gummosus \\
\hline $76-355 A^{T}$ & Mulegé, Baja California, Mexico & S. gummosus \\
\hline $82-410 \mathrm{~A}$ & Fond Parisienne, Haiti & N. paniculata \\
\hline $82-447 \mathrm{~B}, 82-451 \mathrm{~A}$ & Gonnaïves, Haiti & S. hystrix \\
\hline $82-473 \mathrm{~A}, 82-477,82-478 \mathrm{~B}, 82-481 \mathrm{~A}$ & Galeon, Dominican Republic & S. hystrix \\
\hline $82-497 \mathrm{~A}, 82-500 \mathrm{~A}, 82-513 \mathrm{C}$ & Hatillo, Dominican Republic & S. hystrix \\
\hline $82-514 \mathrm{~A}, 82-516 \mathrm{~A}, 82-517 \mathrm{~A}, 82-526 \mathrm{~B}, 82-535 \mathrm{~A}$ & Azua, Dominican Republic & S. hystrix \\
\hline $82-540 \mathrm{~A}$ & YaYa, Dominican Republic & S. hystrix \\
\hline $82-591 \mathrm{~B}, 82-613 \mathrm{~B}$ & Beef Island, Tortola, British West Indies & Cephalocereus royenii \\
\hline $82-621 \mathrm{D}$ & Beef Island, Tortola, British West Indies & O. moniliforme \\
\hline $\begin{array}{l}83-911.2,83-913.1,83-915.1,83-916.1,83-918.1,83-919.1 \\
83-922.2,83-925.1,83-926.1,83-927.2,83-928.1,83- \\
963.1,83-966,83-968.1\end{array}$ & Hellshire Hills, Jamaica & S. hystrix \\
\hline 83-1027.2 & Palisadoes, Jamaica & S. hystrix \\
\hline
\end{tabular}

${ }^{a}$ UCD-FST, University of California at Davis Department of Food Science and Technology.

reference. The buoyant density of the $M$. luteus DNA was derived from comparison with plasmid-free Escherichia coli K-12 DNA, the buoyant density of which was taken to be $1.7100 \mathrm{~g} / \mathrm{ml}$. Denaturation of DNA, incubation for reassociation, analysis of the renaturation kinetics and reannealing reactions, and quantitation of single- and double-stranded DNAs were carried out by using the methods of Price et al. (7). Samples were counted with a TM Analytic model 1290 gamma ray counter ( $84 \%$ efficiency).

Single ascospores were isolated from mature asci with a micro-manipulator (2).

\section{RESULTS}

The morphological properties and sporulation of Pichia deserticola resemble those of Pichia cactophila (11). Physiologically, however, Pichia deserticola differs from Pichia cactophila by its assimilation of ethyl acetate and its inability to utilize glucosamine as a carbon source. Moreover, its $\mathrm{G}+\mathrm{C}$ content of nuclear DNA $(\simeq 27.8 \mathrm{~mol} \%)$ is much lower than that of Pichia cactophila $(\simeq 36.0 \mathrm{~mol} \%)$ (Table 2$)$. However, its low DNA base composition is close to the values for several other as-yet-undescribed species that have as their habitats the necrotic tissues of cacti (Table 2), as well as the non-cactus-specific yeast Pichia kluyveri. The similarities in habitat and base composition induced us to carry out DNA-DNA base sequence complementarity studies (Table 3 ). In one study (Table 3 , experiment 1) Pichia deserticola (the reference species) was compared with isolates from different geographic areas, including strains of Candida deserticola, and strains of other yeasts having similar habitats or $\mathrm{G}+\mathrm{C}$ contents. Table 3 shows that Candida deserticola strains from columnar cacti had 95 to
$100 \%$ DNA complementarity with the type strain of Pichia deserticola. Other species included in this study gave 16 to $18 \%$ relative binding with the type strain of Pichia deserticola, values which are somewhat higher than normally found with distantly related yeasts. To determine whether these values were reproducible, we designed a study (Table 3 , experiment 2) which included two other cactus-specific yeasts as negative controls (Pichia antillensis and Dipodascus australiensis). Four of the species used in the first study gave similar high values, but the two additional negative controls gave low DNA complementarity values. Although Pichia cactophila and Pichia kluyveri appear to have some DNA base sequences in common with Pichia deserticola and its anamorph, the latter yeasts are sufficiently distinct to be described here as new species.

Latin diagnosis of Pichia deserticola sp. nov. In extracto malti post dies 3 cellulae ovoideae, vel ellipsoideae, 3.2-5.5 $\times 4.8-8.0 \mu \mathrm{m}$, singulae, binae, aut in catenis brevis; sedimentum tenue et interdum pellicula tenuis, non-nitida. Post dies 14 annulus et interdum pellicula formantur.

Cultura in agaro malti post dies $18\left(25^{\circ} \mathrm{C}\right)$ butyrosa vel mollis, cremea, glabra, semi-nitida, demissa convexa, margo plana, lobata, aut glabra.

In agaro farinae Zea mays post dies 10 pseudomycelium nullum vel rudimentarium.

Species diploidea, homothallica. Asci inconjugati fiunt, habentes 2 sporos pileiformos in quoque asco; asci rumpunter.

Fermentatio glucosi nulla. Glucosum, ethanolum, glycerolum (lente et exigue), acidum lacticum, acidum succinicum et ethylacetas assimilantur at non galactosum, L-sorbosum, maltosum, saccharosum, cellobiosum, trehalosum, lactos- 
um, melibiosum, raffinosum, melezitosum, inulinum, amylum solubile, D-xylosum, L-arabinosum, D-arabinosum, D-ribosum, L-rhamnosum, methanolum, i-erythritolum, ribitolum, galactitolum, D-mannitolum, D-glucitolum, methyl- $\alpha-D-$ glucosidum, salicinum, glucono- $\delta$-lactonum, kalium-gluconatum, 2- et 5-ketogluconatum, meso-inositolum, glucosaminum, $N$-acetylglucosaminum, acetonum, nec 2-propanolum.

Kalium nitricum et natrium nitrosum non assimilantur. Ethyl aminum, cadaverinum, et lysinum assimilantur.

Ad crescentiam biotinum, thiaminum, et pyridoxinum necessaria sunt.

Crescere potest in $39^{\circ} \mathrm{C}$ at non in $42^{\circ} \mathrm{C}$.

Crescere potest in $5 \% \mathrm{NaCl}$, exigue in $7.5 \% \mathrm{NaCl}$, at non in $10 \% \mathrm{NaCl}$.

$\mathrm{G}+\mathrm{C}$ acidi deoxyribonucleati, $27.8 \pm 0.4 \mathrm{~mol} \%$ (8 stirpes).

Habitatio: species opuntiae.

Typus: stirps UCD-FST 83-467.3 ex tabidosus sacculis cacti Opuntia phaeacantha isolata est.

In collectione zymotica Centraalbureau voor Schimmelcultures, Delphi Batavorum, sub no. 7119 deposita est.

Latin diagnosis of Candida deserticola sp. nov Candida deserticola eadem est ac Pichia deserticola praeter absentia ascosporarum.

$\mathrm{G}+\mathrm{C}$ acidi deoxyribonucleati, $27.5 \pm 0.3 \mathrm{~mol} \%$ (8 stirpes).

Habitatio: species stenocerei.

Typus: stirps UCD-FST 76-355A ex tabidosis sacculis cacti $S$. gummosus isolata est.

In collectione zymotica Centraalbureau voor Schimmelcultures, Delphi Batavorum, sub no. 7121 deposita est.

Standard description of Pichia deserticola. In malt extract after 3 days at $25^{\circ} \mathrm{C}$, the cells are quite uniform, vary from ovoid to ellipsoidal, are 3.2 to 5.5 by 4.8 to $8.0 \mu \mathrm{m}$, and occur singly, in pairs, and in small clusters or chains of three

TABLE 2. Nuclear DNA base compositions ( $G+C$ contents) of Pichia deserticola, Candida deserticola, and other species used in DNA-DNA reassociation studies

\begin{tabular}{|c|c|c|}
\hline $\begin{array}{l}\text { UCD-FST } \\
\text { strain no. }\end{array}$ & Organism & $\begin{array}{l}\mathrm{G}+\mathrm{C} \\
\text { content } \\
(\mathrm{mol} \%)\end{array}$ \\
\hline $83-467.3^{\mathrm{T}}$ & Pichia deserticola & $27.4 \pm 0.3$ \\
\hline $81-403 B$ & Pichia deserticola & $27.6 \pm 0.3$ \\
\hline $81-632.1$ & Pichia deserticola & $27.7 \pm 0.3$ \\
\hline 81-413D & Pichia deserticola & $27.9 \pm 0.3$ \\
\hline $81-448 \mathrm{C}$ & Pichia deserticola & $27.8 \pm 0.4$ \\
\hline $81-610.2$ & Pichia deserticola & $27.8 \pm 0.3$ \\
\hline $81-626.1$ & Pichia deserticola & $28.4 \pm 0.4$ \\
\hline $81-628.2$ & Pichia deserticola & $27.9 \pm 0.4$ \\
\hline $72-305$ & Candida deserticola & $27.2 \pm 0.2$ \\
\hline $76-240 \mathrm{~A}$ & Candida deserticola & $27.6 \pm 0.5$ \\
\hline $76-355 \mathrm{~A}^{\mathrm{T}}$ & Candida deserticola & $27.5 \pm 0.3$ \\
\hline $76-229 B$ & Candida deserticola & $27.5 \pm 0.2$ \\
\hline $76-341 \mathrm{~A}$ & Candida deserticola & $27.7 \pm 0.2$ \\
\hline $82-451 \mathrm{~A}$ & Candida deserticola & $27.4 \pm 0.2$ \\
\hline 82-591B & Candida deserticola & $27.5 \pm 0.2$ \\
\hline 83-963.1 & Candida deserticola & $27.5 \pm 0.1$ \\
\hline $\mathrm{C}-7^{\mathrm{T}}$ & Pichia kluyveri & $30.2 \pm 0.3$ \\
\hline 76-296B & Candida sp. A & $30.0 \pm 0.4$ \\
\hline 76-367B & Pichia cactophila & $36.4 \pm 0.2$ \\
\hline $77-427^{\mathrm{T}}$ & Pichia pseudocactophila & $36.8 \pm 0.3$ \\
\hline $76-245 \mathrm{C}$ & Pichia norvegensis & $37.4 \pm 0.4$ \\
\hline $83-466.1$ & Pichia sp. T & $29.8 \pm 0.2$ \\
\hline $77-165$ & Pichia sp. B & $30.1 \pm 0.5$ \\
\hline $82-651 A^{T}$ & Pichia antillensis & $33.7 \pm 0.3$ \\
\hline $\mathrm{G}-32^{\mathrm{T}}$ & Dipodascus australiensis & $39.9 \pm 0.3$ \\
\hline
\end{tabular}

${ }^{a}$ Average \pm standard deviation from three or more buoyant density determinations. to six cells. There is little sediment and usually a thin, smooth, dull pellicle; in some strains only a thin ring is formed. In older cultures the sediment increases, and a thin ring and pellicle or islets persist.

On malt agar after 18 days at $25^{\circ} \mathrm{C}$, streak cultures are low convex, little spreading, grayish, semidull to semiglossy, smooth, and soft, with borders that are entire to lobulate, flat, and slightly transparent to glossy.

In Dalmau plate cultures on cornmeal agar after 10 days a pseudomycelium is absent in the aerobic portion of growth. Under a cover slip pseudomycelium is either absent or spotty and rudimentary.

The vegetative cells are diploid. Sporulation in vegetative cells appears to occur best on acetate agar at about $25^{\circ} \mathrm{C}$ in about 7 days or on dilute ( 2 to $3 \%$ ) malt extract agar. The asci contain two hat-shaped spores which are released rapidly from the ascus (Fig. 1) upon maturity. The brims of the rather large spores are best seen after the asci dehisce. Single ascospores isolated with a micro-manipulator give rise to sporulating cultures, suggesting that Pichia deserticola is homothallic.

Ability to ferment glucose is lacking. The carbon compounds D-glucose, ethanol, glycerol (weak, latent), lactic acid, succinic acid, and ethyl acetate are assimilated.

The following carbon compounds are not assimilated: D-galactose, L-sorbose, maltose, sucrose, cellobiose, trehalose, lactose, melibiose, raffinose, melezitose, inulin, soluble starch, D-xylose, L-arabinose, D-arabinose, Dribose, L-rhamnose, methanol, i-erythritol, ribitol, galactitol, D-mannitol, D-glucitol, methyl- $\alpha$-D-glucoside, salicin, glucono- $\delta$-lactone, potassium gluconate, 2-ketogluconate, 5-ketogluconate, citric acid, meso-inositol, glucosamine hydrochloride, $\mathrm{N}$-acetyl-D-glucosamine, acetone, 2-propanol, and hexadecane.

Assimilation of nitrogen compounds: potassium nitrate and sodium nitrite negative; ethylamine, cadaverine, lysine, and ammonium sulfate positive.

Growth in a vitamin-free medium is negative. Biotin, thiamine, and pyridoxine are required for growth.

Growth in amino acid-free medium supplemented with $\left(\mathrm{NH}_{4}\right)_{2} \mathrm{SO}_{4}$ is positive.

Growth on $50 \%$ (wt/wt) glucose-yeast extract agar is negative.

Growth on glucose-yeast extract agar containing $5 \% \mathrm{NaCl}$ is positive, growth on the same medium containing $7.5 \%$ $\mathrm{NaCl}$ is weak, and growth in the presence of $10 \% \mathrm{NaCl}$ is negative.

Maximum temperature for growth: positive at $39^{\circ} \mathrm{C}$, negative at $42^{\circ} \mathrm{C}$.

Acid formation on chalk agar negative or weak.

Hydrolysis of urea negative.

Gelatin liquefaction negative.

Casein hydrolysis negative.

Lipolytic activity negative.

Growth in the presence of $1 \mu \mathrm{g}$ of cycloheximide per $\mathrm{ml}$ is negative.

$\mathrm{G}+\mathrm{C}$ content of the nuclear DNA, 27.4 to $28.4 \mathrm{~mol} \%$ (eight strains) (Table 2); average \pm standard deviation for eight strains, $27.8 \pm 0.4 \mathrm{~mol} \%$.

Habitat. A total of 21 strains were recovered from necrotic tissues of $O$. phaeacantha in the mountains surrounding Tucson, Ariz., and from Opuntia lindheimeri in Texas (Table 1).

Type. The type strain of Pichia deserticola, strain UCDFST 83-467.3, was isolated from rotting cladodes of $O$. phaeacantha in the Santa Catalina Mountains near Tucson; 
TABLE 3. Reannealing between labeled DNA from Pichia deserticola UCD-FST $83-467.3^{\mathrm{T}}$ and DNAs from 17 yeast strains and calf thymus DNA at $59.4^{\circ} \mathrm{C}^{a}$

\begin{tabular}{|c|c|c|c|c|c|c|}
\hline \multirow[b]{2}{*}{ Organism or tissue } & \multicolumn{3}{|c|}{ Expt 1} & \multicolumn{3}{|c|}{ Expt 2} \\
\hline & $\begin{array}{c}\text { Actual } \\
\text { binding (\%) }\end{array}$ & $\begin{array}{c}\text { Corrected } \\
\text { actual } \\
\text { binding }(\%)^{b}\end{array}$ & $\begin{array}{c}\text { Reląive } \\
\text { binding }(\%)^{b}\end{array}$ & $\begin{array}{c}\text { Actual } \\
\text { binding (\%) }\end{array}$ & $\begin{array}{c}\text { Corrected } \\
\text { actual } \\
\text { binding }(\%)^{c}\end{array}$ & $\begin{array}{c}\text { Relative } \\
\text { binding }(\%)^{c}\end{array}$ \\
\hline $\begin{array}{l}\text { Pichia deserticola } \\
\text { UCD-FST } 83-467.3^{\mathrm{T}}\end{array}$ & $74.2 \pm 1.0^{c}$ & 73.7 & 100.0 & $75.7 \pm 0.6^{c}$ & 75.2 & 100.0 \\
\hline $\begin{array}{l}\text { Pichia deserticola } \\
\text { UCD-FST 81-403B }\end{array}$ & $74.4 \pm 0.9$ & 73.8 & 100.2 & $74.9 \pm 0.6$ & 74.4 & 98.9 \\
\hline $\begin{array}{l}\text { Pichia deserticola } \\
\text { UCD-FST 81-632.1 }\end{array}$ & $74.0 \pm 1.0$ & 73.5 & 99.7 & & & \\
\hline $\begin{array}{c}\text { Candida deserticola } \\
\text { UCD-FST 72-305 }\end{array}$ & $76.5 \pm 0.2$ & 76.0 & 103.1 & & & \\
\hline $\begin{array}{l}\text { Candida deserticola } \\
\text { UCD-FST 76-240A }\end{array}$ & $71.0 \pm 1.0$ & 70.4 & 95.5 & & & \\
\hline $\begin{array}{l}\text { Candida deserticola } \\
\text { UCD-FST } 76-355 \mathrm{~A}^{\mathrm{T}}\end{array}$ & $73.8 \pm 0.6$ & 73.2 & 99.4 & & & \\
\hline $\begin{array}{l}\text { Candida deserticola } \\
\text { UCD-FST 82-451A }\end{array}$ & $71.1 \pm 0.7$ & 70.5 & 95.7 & & & \\
\hline $\begin{array}{l}\text { Candida deserticola } \\
\text { UCD-FST 82-591B }\end{array}$ & $71.4 \pm 0.4$ & 70.7 & 96.0 & & & \\
\hline $\begin{array}{l}\text { Candida deserticola } \\
\text { UCD-FST 83-963.1 }\end{array}$ & $71.1 \pm 0.4$ & 70.4 & 95.6 & & & \\
\hline $\begin{array}{l}\text { Pichia kluyveri } \\
\text { UCD-FST C-7 }\end{array}$ & $15.2 \pm 0.4$ & 13.3 & 18.1 & $16.5 \pm 0.5$ & 14.7 & 19.6 \\
\hline $\begin{array}{l}\text { Pichia cactophila } \\
\text { UCD-FST 76-367B }\end{array}$ & $14.8 \pm 0.9$ & 12.9 & 17.5 & $14.9 \pm 0.5$ & 13.2 & 17.5 \\
\hline $\begin{array}{l}\text { Pichia sp. B strain } \\
\text { UCD-FST } 77-165\end{array}$ & $13.7 \pm 0.2$ & 11.8 & 16.0 & $14.2 \pm 0.1$ & 12.5 & 16.6 \\
\hline $\begin{array}{l}\text { Pichia sp. T strain } \\
\text { UCD-FST } 83-466.1\end{array}$ & $13.8 \pm 0.6$ & 11.9 & 16.2 & $14.4 \pm 0.5$ & 12.6 & 16.7 \\
\hline $\begin{array}{l}\text { Candida sp. A strain } \\
\text { UCD-FST 76-296B }\end{array}$ & $14.0 \pm 0.5$ & 12.1 & 16.4 & & & \\
\hline $\begin{array}{l}\text { Pichia norvegensis } \\
\text { UCD-FST 76-245C }\end{array}$ & & & & $9.7 \pm 0.3$ & 7.8 & 10.4 \\
\hline $\begin{array}{l}\text { Pichia pseudocactophila } \\
\text { UCD-FST } 77-427^{\mathrm{T}}\end{array}$ & & & & $10.5 \pm 0.2$ & 8.6 & 11.5 \\
\hline $\begin{array}{l}\text { Pichia antillensis } \\
\text { UCD-FST } 82-651 \mathrm{~A}^{\mathrm{T}}\end{array}$ & & & & $6.1 \pm 0.1$ & 4.1 & 5.5 \\
\hline $\begin{array}{l}\text { Dipodascus australiensis } \\
\text { UCD-FST G-32 }\end{array}$ & & & & $2.8 \pm 0.2$ & 0.8 & 1.1 \\
\hline Calf thymus & $3.4 \pm 0.4$ & 1.3 & 1.7 & $2.9 \pm 0.4$ & 0.9 & 1.2 \\
\hline
\end{tabular}

${ }^{125}$ I-labeled DNA $(0.2 \mu \mathrm{g})$ and unlabeled DNA $(200 \mu \mathrm{g})$ were incubated for $25 \mathrm{~h}$ in $0.5 \mathrm{ml}$ of $280 \mathrm{mM}$ phosphate buffer.

${ }^{b}$ Corrected for self-renaturation (experiment $1,2.2 \pm 0.7 \%$; experiment $2,2.1 \pm 0.4 \%$ ) (7).

"Average \pm standard deviation for three samples (corrected for zero-time binding).

this strain has been deposited in the collection of the Yeast Division of the Centraalbureau voor Schimmelcultures, Delft, The Netherlands, as strain CBS 7119 and in the American Type Culture Collection, Rockville, Md., as strain ATCC 58091.

Etymology. The specific epithet of Pichia deserticola (de. sert'i. co. la. L. f. noun desertum desert; L. m. noun incola inhabitant; L. m. noun deserticola dweller of the desert) refers to its habitat.

Supplementary description of Candida deserticola. The morphological and physiological properties of Candida deserticola are the same as those of Pichia deserticola.

Ascospore formation has not been observed on various sporulation media.

$\mathrm{G}+\mathrm{C}$ content of the nuclear DNA, 27.2 to $27.7 \mathrm{~mol} \%$ (eight strains) (Table 2); average \pm standard deviation for eight strains, $27.5 \pm 0.3 \mathrm{~mol} \%$.

Habitat. Most strains were isolated from columnar cacti. A total of 15 strains were recovered from the columnar cactus $S$. hystrix, and a single strain was recovered from Neoabbotlia paniculata on the island of Hispagnola. Two strains came from Cephalocereus royenii, and one came from Opuntia moniliforme on the island of Tortola in the British West Indies. On the island of Jamaica 15 strains were recovered from $S$. hystrix rots. In southern and central Baja California nine strains came from rots in $S$. gummosus, two came from Stenocereus thurberi, and one came from the slime flux of Prosopis juliflora. Two strains were isolated from Carnegiea gigantea in southern Arizona.

\section{DISCUSSION}

Pichia deserticola appears to have as its habitat rotting cladodes of $O$. phaeacantha and $O$. lindheimeri in the southwestern United States, because 14 strains were isolated in October 1981 in various geographic regions and an additional 7 strains were isolated in April 1983 during a more limited survey in southern Arizona (Table 1). Pichia deserticala was not found in rots of Opuntia ficus-indica in the same region (10), in Australian Opuntia stricta plants (1), or in rotting Opuntia stricta occurring on various Caribbean islands which are outside the Sonoran Desert (Starmer and Phaff, unpublished data). Presumably the yeast is maintained 

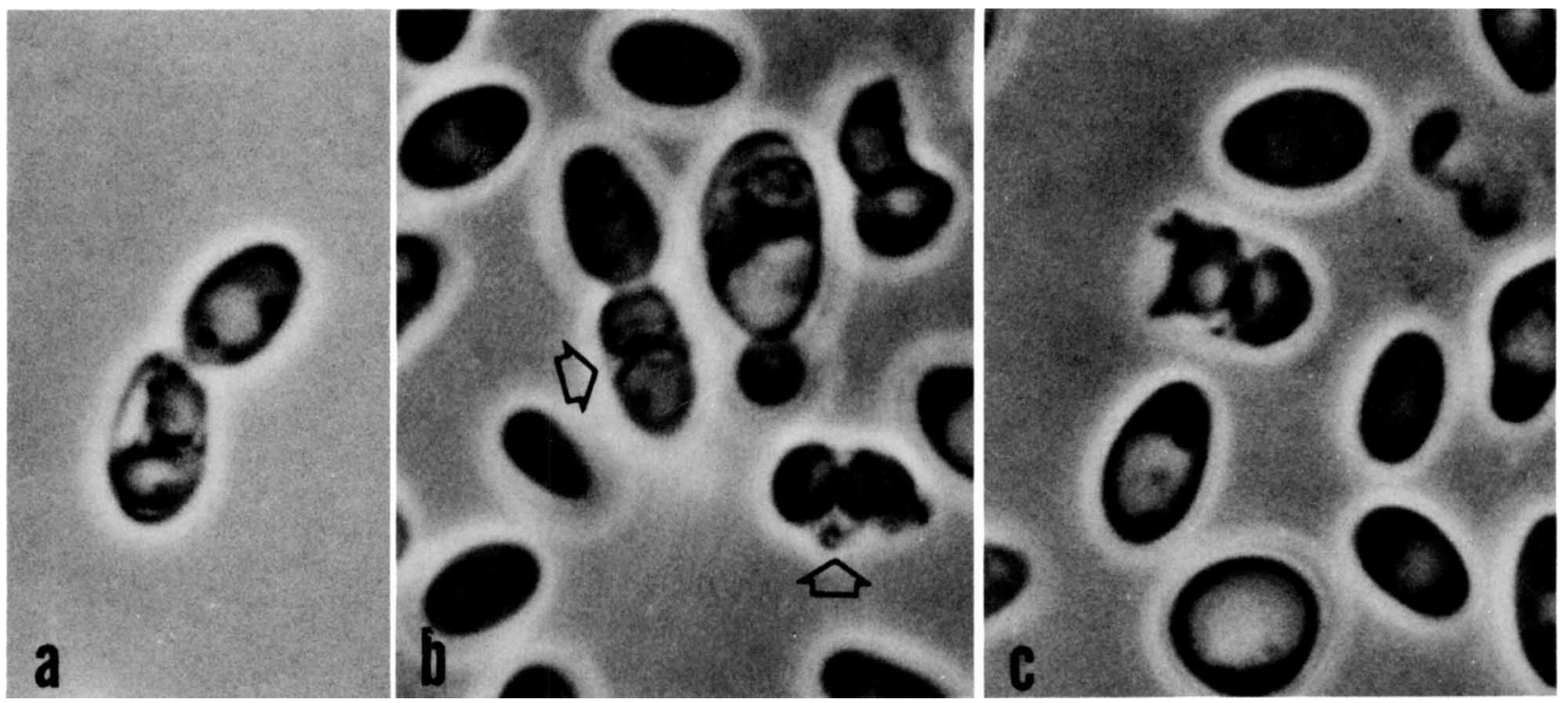

FIG. 1. Asci and ascospores of Pichia deserticola. (a) Ascus with two spores. The brims of the spores are obscured by cytoplasmic remnants. (b) Arrows indicate two mature asci in the process of dehiscence by wall lysis. In the upper right is a pair of liberated ascospores. (c) Pair of liberated ascospores with distinct brims. Spore pairs are nearly always in a non-brim-to-brim position. In the upper right is a recently dehisced ascus remnant.

in its habitat by specific Drosophila species that breed in $O$. phaeacantha and $O$. lindheimeri. Pichia deserticola superficially resembles Pichia cactophila and could be confused with that species if an expanded spectrum of carbon compounds were not used; i.e., in contrast to Pichia cactophila, Pichia deserticola does not utilize D-glucosamine as a carbon source but grows strongly on ethyl acetate. Citrate is utilized by nearly all strains of Pichia cactophila, but not by any Pichia deserticola strain. In addition, there is a large difference in nuclear $\mathrm{G}+\mathrm{C}$ content (Table 2). It is surprising that with such a large difference in $\mathrm{G}+\mathrm{C}$ content, Pichia cactophila DNA showed nearly $18 \%$ relative binding to Pichia deserticola DNA (Table 3). Pichia antillensis (14), whose $\mathrm{G}+\mathrm{C}$ content is closer to that of Pichia deserticola, gave only $5.5 \%$ relative binding (Table 3 ), in our experience a more typical value for yeasts whose base compositions differ by more than 2 to $3 \mathrm{~mol} \%$. It is possible that Pichia deserticola, Pichia cactophila, and Pichia kluyveri are descendants of a common ancestor, thus accounting for some residual DNA sequences held in common. Alternatively, because Pichia cactophila and Pichia deserticola coexist in the same cactus necroses, it is possible that some genetic exchange might take place between the two species, perhaps resulting in aneuploidy. The same may be true for Pichia kluyveri; recent experiments (Phaff and Tredick, unpublished data) suggest that this species also occurs in Opuntia rots in the same area. On the other hand, Pichia antillensis is geographically isolated from Pichia deserticola and has been found only on some islands of the Lesser Antilles (14). Previous evidence for genetic exchange between different homothallic species of the genus Kluyveromyces was reported by van der Walt and Johannsen (16). Kurtzman et al. (6) presented evidence that such hybrids between species with large differences in $\mathrm{G}+\mathrm{C}$ content in all likelihood represent aneuploid strains with poor spore viability.

Candida deserticola has the same morphological and physiological properties as Pichia deserticola, and, as shown in Table 3 , its DNA base sequence arrangement is virtually identical to that of its teleomorph. Its habitat, however, is different, both in host plant and geography (Table 1). The question arises as to why the strains from Opuntia sporulate, whereas those from columnar cacti do not. Almost all strains of Candida deserticola were isolated from species of Stenocereus (Table 1), a genus belonging to the subtribe Stenocereinae of the tribe Pachycereeae (3). Members of this subtribe are characterized by abundant triterpene glycosides in their stems, whereas members of the subtribe Pachycereinae and of the tribe Opuntieae lack triterpene glycosides $(3,5)$. Starmer et al. (9) demonstrated that the growth of certain yeasts that inhabit species of the Pachycereinae is inhibited at $25^{\circ} \mathrm{C}$ in laboratory media containing $1 \%$ dried powdered $S$. gummosus tissue. Yeast species which inhabit species of the Stenocereinae are generally resistant at room temperature. In the cactus-specific yeast Pichia amethionina (12), this susceptibility to triterpene glycosides is controlled by at least one temperature-sensitive gene (the permissive temperature is $\left.37^{\circ} \mathrm{C}\right)(9)$. We feel that the chemical composition of Stenocereus species (possibly their high triterpene glycoside contents) may be the cause of the loss of sporulating ability in strains of Candida deserticola. We have found that strains of Pichia deserticola are inhibited at $25^{\circ} \mathrm{C}$ by $1 \%$ $S$. gummosus powder in yeast autolysate-glucose agar, but strains of Candida deserticola grow well in this medium. Further support for the possible effect of triterpene glycosides on sporulation was obtained with strains of Pichia cactophila isolated from $S$. hystrix and $O$. stricta growing sympatrically on some Caribbean islands. The strains from Opuntia sporulated heavily, but those from Stenocereus were asporogenous. A possibly similar effect of triterpene glycosides on sporulation may apply to Pichia amethionina (12). Pichia amethionina var. amethionina, which inhabits members of the subtribe Stenocereinae, sporulates slowly upon mixing of compatible mating types, whereas Pichia amethionina var. pachycereana, which inhabits species of the subtribe Pachycereinae, sporulates very rapidly under the same conditions. It may be possible to verify the effect of Stenocereus stem chemicals on sporulation of Pichia deserticola and Pichia cactophila by growing these species at 
$37^{\circ} \mathrm{C}$ (the permissive temperature) in the presence of $S$. gummosus powder and periodically checking them for sporulation ability.

\section{ACKNOWLEDGMENTS}

This work was supported by grants DEB $81-08679$ (to W.T.S.) and DEB 81-08898 (to H.J.P.) from the National Science Foundation.

\section{LITERATURE CITED}

1. Barker, J. S. F., G. L. Toll, P. D. East, M. Miranda, and H. J. Phaff. 1983. Heterogeneity of the yeast flora in the breeding sites of cactophilic Drosophila. Can. J. Microbiol. 29:6-14.

2. Fowell, R. R. 1969. Sporulation and hybridization of yeasts, p. 303-383. In A. H. Rose and J. S. Harrison (ed.), The yeasts, vol. 1. Academic Press, Inc., New York.

3. Gibson, A. C., and K. E. Horak. 1978. Systematic anatomy and phylogeny of Mexican columnar cacti. Ann. Mo. Bot. Gard. 65:999-1057.

4. Holzschu, D. L., H. L. Presley, M. Miranda, and H. J. Phaff. 1979. Identification of Candida lusitaniae as an opportunistic yeast in humans. J. Clin. Microbiol. 10:202-205.

5. Kircher, H. W. 1982. Chemical composition of cacti and its relationship to Sonoran Desert Drosophila, p. 143-158. In J. S. F. Barker and W. T. Starmer (ed.), Ecological genetics and evolution, the cactus-yeast-Drosophila model system. Academic Press Australia, Sydney.

6. Kurtzman, C. P., H. J. Phaff, and S. A. Meyer. 1983. Nucleic acid relatedness among yeasts, p. 139-166. In J. F. T. Spencer, D. M. Spencer, and A. R. W. Smith (ed.), Yeast genetics, fundamental and applied aspects. Springer-Verlag, New York.

7. Price, C. W., G. B. Fuson, and H. J. Phaff. 1978. Genome comparison in yeast systematics: delimitation of species within the genera Schwanniomyces, Saccharomyces, Debaryomyces, and Pichia. Microbiol. Rev, 42:161-193.

8. Schildkraut, C. L., J. Marmur, and P. Doty. 1962. Determination of the base composition of deoxyribonucleic acid from its buoyant density in CsCl. J. Mol. Biol. 4:430-433.

9. Starmer, W. T., H. W. Kircher, and H. J. Phaff. 1980. Evolution and speciation of host plant specific yeasts. Evolution 34: 137-146.

10. Starmer, W. T., and H. J. Phaff. 1983. Analysis of the community structure of yeasts associated with the decaying stems of cactus. II. Opuntia species. Microb. Ecol. 9:247-259.

11. Starmer, W. T., H. J. Phaff, M. Miranda, and M. W. Miller. 1978. Pichia cactophila, a new species of yeast found in decaying tissue of cacti. Int. J. Syst. Bacteriol. 28:318-325.

12. Starmer, W. T., H, J. Phaff, M. Miranda, and M. W. Miller. 1978. Pichia amethionina, a new heterothallic yeast associated with decaying stems of cereoid cacti. Int. J. Syst. Bacteriol. 28:433-441.

13. Starmer, W. T., H. J. Phaff, M. Miranda, M. W. Miller, and W. B. Heed. 1982. The yeast flora associated with the decaying stems of columnar cacti and Drosophila in North America. Evol. Biol. 14: 269-295.

14. Starmer, W. T., H. J. Phaff, J. Tredick, M. Miranda, and V. Aberdeen. 1984. Pichia antillensis, a new species of yeast associated with necrotic stems of cactus in the Lesser Antilles, Int. J. Syst. Bacteriol. 34:350-354.

15. Szybalski, W. 1969. Use of cesium sulfate for equilibrium density gradient centrifugation. Methods Enzymol. 12:330-360.

16. van der Walt, J. P., and E. Johannsen. 1979. A comparison of interfertility and in vitro DNA-DNA reassociation as criteria for speciation in the genus Kluyveromyces. Antonie van Leeuwenhoek J. Microbiol. Serol. 45:281-291.

17. van der Walt, J. P., and D. Yarrow. 1984. Methods for the isolation, maintenance, classification and identification of yeasts, p. 45-104. In N. J. W. Kreger-van Rij (ed.), The yeasts-a taxonomic study. North-Holland Publishing Co., Amsterdam. 